ІННОВАЦІї

UDC 3470.73

\author{
A. O. Kasych, Doctor of Economic \\ Sciences, Professor, \\ M. Vochozka, Doctor of Philosophy \\ Sciences (Economics)
}

\section{CONCEPTUAL PROVISIONS OF THE DEVELOPMENT OF UKRAINIAN NATIONAL INNOVATION SYSTEM}

Urgency of the research. In most countries the national innovation system concept (NIS) is used to justify the economic policy content and to aim development at an innovative path as the basic one.

Target setting. The theoretical and practical justification question regarding the content of the NIS development concept in Ukraine still remain relevant.

Actual scientific researches and issues analysis. The conceptual issues of the NIS development in different groups of countries have been studied in the works of prominent foreign and Ukrainian scholars, in particular, by R. D. Atkinson, V. M. Heyets, B. Godina, B. A. Lundvall, L. I. Fedulovoyi, S. Feinson, C. Freeman.

Uninvestigated parts of general matters defining. Article should investigate the existence of differences between the NIS concept in developed and developing countries.

The research objective. To analyze the NIS differences of developed and developing countries and to formulate the conceptual provisions for the NIS formation in Ukraine.

The statement of basic materials. The article systematizes the existing scientific approaches to the development of national innovation systems (NISs), determines the NIS value for the development of a country. It emphasizes the existence of differences between the NIS concept in developed and developing countries.

The article presents the development of basic points of the NIC concept that are the most important to understand its nature.

Conclusions. The complexity of the NIS formation causes even some doubts as for the effective implementation of this concept in developing countries. It means that the NIS concept content and a set of tools for implementation requires a clear, scientific justification based on a strategic approach. This long-term strategy of innovative development by improving NIS can be considered the starting point of a state policy in the innovative sphere that will enable a country to develop adequate implementation toolkit and transform it into a legislative framework, targeted and comprehensive development programs.

Keywords: innovation; concept; system; differences function.

DOI:10.25140/2410-9576-2017-2-2(10)16-23

Urgency of the research. The economic development in the XXI century is not based on natural resources only, but, primarily, depends on the opportunities which come out of knowledge and innovation.
УДК 3470.73

А. О. Касич, д. е. н.,
профресор,

М. Вохозка, д. фрілос. н.

(економіка)

\section{КОНЦЕПТУАЛЬНІ ПОЛОЖЕННЯ РОЗВИТКУ НАЦІОНАЛЬНОÏ ІННОВАЦІЙНОЇ СИСТЕМИ УКРАЇНИ}

Актуальність теми дослідження. У переважній більшості країн для обґрунтування змісту економічної політики та спрямування розвитку на інноваційний шлях, в якості базисної, використовується концепція національних інноваційних систем (HIC).

Постановка проблеми. Питання теоретикометодологічного обгрунтування змісту концепції розвитку НІС України залишаються актуальними.

Аналіз останніх досліджень і публікацій. Концептуальні питання розбудови НIC у різних групах країнах досліджено в працях зарубіжних та українських вчених, зокрема, Р. Аткінсона, В. М. Гейця, Б. Годіна, Б. Лундвала, Л. І. Федулової, С. Фейнсона, К. Фрімена.

Виділення недосліджених частин загальної проблеми. У статmі досліджено існуючі відмінності між концепціями НІС для розвинених країн та країн, що розвиваються.

Постановка завдання. Проаналізувати існуючі відмінності HIC в розвинених країнах та країнах, які розвиваються та сорормулювати концептуальні положення формування НІС в Україні.

Виклад основного матеріалу. У статmі систематизовано існуючі наукові підходи до розвитку національних інноваційних систем (HIC), визначено значення HIC для розвитку країни. Наголошено на існуванні відмінностей у концепції НІС в розвинених країнах та в країнах, що розвиваються. Також було сформульовано базисні положення концепції НІС, які мають найбільше значення для розуміння їі сутності. Висновки. Складність процесів формування НIC зумовлює, навіть, певні сумніви в ефективній реалізації даної концепції в країнах, що розвиваються. Все це означає, що і зміст концепції НІС та набір інструментів для реалізації потребує чіткого, наукового обгрунтування на засадах стратегічного підходу. Саме довгострокову стратегію інноваційного розвитку через удосконалення НIC можна вважати вихідною точкою реалізації державної політики у сфері інновацій, що дасть можливість державі розробити адекватний інструменбазу, цільові та комплексні програми розвитку.

Ключові слова: інновації; концепція; система; відмінності; функції. тарії реалізації та трансорормувати його в законодавчу 


\section{ІННОВАЦІї}

Nowadays the dependence of economic growth on the ability of a system to produce innovations is observed even more than before, because the dynamics of scientific progress has slowed down, and, therefore, its results are becoming more valuable.

In most countries the national innovation system concept is used to justify the economic policy content and to aim development at an innovative path as the basic one.

It has been designed for developed countries and represents a clear orientation of all socioeconomic processes and institutional transformations to innovative benchmarks.

Developing countries are in a catching up state, so their focus on innovation is also significant. Herewith, the NIS formation in these countries is one of the most dynamic processes.

The national innovation system concept was approved in Ukraine in 2009. In accordance with the concept, ambitious plans to provide innovative national economy and obtain significant results in 2025 were set.

However, half of the period has already passed, but the results stated in the programme are still unattainable. This means that the designed concept has had a declarative nature and it has not provided real management mechanisms of the entire innovation sector.

That is why, the theoretical and practical justification question regarding the content of the NIS development concept in Ukraine, and ensuring its tools for its effective implementation still remain relevant.

Actual scientific researches and issues analysis. The conceptual issues of the NIS development in different groups of countries have been studied in the works of prominent foreign and Ukrainian scholars, in particular, by R. D. Atkinson [4], V. M. Heyets [1], B. Godin [8], B. A. Lundvall [9], L. I. Fedulovoyi [3], S. Feinson [6], C. Freeman [7].

K. Freeman's [7] article, which can be considered as a "pioneering" one, reveals the evolution of the innovation role in economic development, summarizes the experience of many countries and leads to understanding the importance of creating a national innovation system to ensure the promotion of innovations.

The concept of the NIS construction justified by scientists has an important significance because it allows to determine the content of public policies, which is directed at the systemic solution to the objectives of technological development.

Thus, B. Lundval [9] has claimed that the NIS concept is not a theoretical concept, as it takes on different meanings in different contexts, it means that there are certain differences in the NIS functioning, for instance, in developed and developing countries.

According to N. Sherif [11], the significance of the NIS concept, in some aspects, goes beyond economics and has a broad socio-economic and global geopolitical context.

The existing differences in innovation activity in developed and developing countries, have been studied in the works by $[2 ; 5 ; 6 ; 10-12]$, which allows us to emphasize the need for further research to understand the NIS concept for developing countries.

The objectives of the article. Considering the importance the NIS formation for Ukraine, to our mind, it is necessary:

Firstly, to analyze the NIS differences of developed and developing countries, that will determine the regularities of these processes;

Secondly, to formulate the conceptual provisions for the NIS formation in Ukraine, which should get out of the catching-up country position during 10-15 years using the innovative characteristics.

Main part. In modern conditions the competitiveness of developed countries is based on their technological leadership, which is the result of the effective national innovation system (NIS). However NIS in developed countries continue to evolve, as always there is a dynamic environment and the changing of innovation determinants causes the changes all NIS.

Regardless the fact that the NIS concept in developed countries has been crystallized by stages and considering the most positive experience, its automatic application in any country is impossible.

Since conditions in each country differ significantly, the basic NIS provisions cannot be mechanically transferred into a very different social, economic and cultural environment and provide the same results. 
ІННОВАЦІї

Despite the fact that developing countries actively solve problems of industrial development, they have also taken the innovation-oriented model as the basis, but they did that later in time, and, therefore, the results, which they have received are somewhat more modest.

As a result, there are some differences between developed and developing countries.

Using the results of the analytical studies in OECD countries and their research enables to analyze the performance more comprehensively and to identify the differences of the NIS in different groups of countries (Tab. 1).

Table 1

Differences in NIS in developed and developing countries

\begin{tabular}{|c|c|c|}
\hline \\
\hline Criteria & Developed countries & Developing countries \\
\hline \multicolumn{3}{|l|}{ I. Features: } \\
\hline $\begin{array}{l}\text { The purpose of the } \\
\text { operation }\end{array}$ & $\begin{array}{l}\text { The realization of a sustainable develop- } \\
\text { ment concept through the innovation im- } \\
\text { plementation in all spheres of society }\end{array}$ & $\begin{array}{l}\text { Overcoming the economic develop- } \\
\text { ment lag by forming innovative sector }\end{array}$ \\
\hline $\begin{array}{l}\text { The composition of } \\
\text { subsystems and compo- } \\
\text { nents }\end{array}$ & $\begin{array}{l}\text { The creation of new innovation infrastruc- } \\
\text { ture elements is taking place }\end{array}$ & $\begin{array}{l}\text { The pre-existing elements of the in- } \\
\text { novative infrastructure are continuing } \\
\text { to function. New forms of the innova- } \\
\text { tion operation have limited develop- } \\
\text { ment. }\end{array}$ \\
\hline $\begin{array}{l}\text { The interaction be- } \\
\text { tween the elements }\end{array}$ & $\begin{array}{l}\text { The high level of efficiency of interaction } \\
\text { of the existing institutions }\end{array}$ & $\begin{array}{l}\text { Fragmented interaction, lack of real } \\
\text { cooperation, the problem of coordina- } \\
\text { tion }\end{array}$ \\
\hline $\begin{array}{l}\text { The sources of innova- } \\
\text { tion (mechanisms) }\end{array}$ & $\begin{array}{l}\text { Self-sufficient innovative systems that de- } \\
\text { velop for the account of domestic sources } \\
\text { of innovation creation }\end{array}$ & $\begin{array}{l}\text { Focused on the exploitation of the } \\
\text { overseas innovation }\end{array}$ \\
\hline $\begin{array}{l}\text { The degree of state } \\
\text { support }\end{array}$ & $\begin{array}{l}\text { An effective set of tools, including the di- } \\
\text { rect research funding, is used }\end{array}$ & $\begin{array}{l}\text { The state uses a limited set of tools } \\
\text { for the stimulation of innovation }\end{array}$ \\
\hline $\begin{array}{l}\text { Directions of scientific } \\
\text { research }\end{array}$ & $\begin{array}{l}\text { The formation of specialization in scien- } \\
\text { tific research }\end{array}$ & $\begin{array}{l}\text { The development of innovations that } \\
\text { are important for the development of } \\
\text { basic industries }\end{array}$ \\
\hline $\begin{array}{l}\text { Priorities in the devel- } \\
\text { opment of science }\end{array}$ & $\begin{array}{l}\text { Funding of the development of new areas } \\
\text { of basic science }\end{array}$ & Applied science for industrialization \\
\hline \multicolumn{3}{|c|}{ II. Quantitative indicators, trends: } \\
\hline $\begin{array}{l}\text { Gross Domestic Ex- } \\
\text { penditure on R\&D }\end{array}$ & $2-3 \%$ GDP, a growth tendency & $\begin{array}{l}\text { less than } 1 \% \text { GDP, a growth ten- } \\
\text { dency }\end{array}$ \\
\hline $\begin{array}{l}\text { Gross Domestic Ex- } \\
\text { penditure on education }\end{array}$ & 4-5\% GDP, a slow growth tendency & 2-4\% GDP, a slow growth tendency \\
\hline $\begin{array}{l}\text { The number of scien- } \\
\text { tific personnel per } 1 \\
\text { thousand employees }\end{array}$ & 10-15 people, a growth tendency & 2-4 people, a growth tendency \\
\hline Capital formation & 17-20\% GDP, a slow decrease tendency & $\begin{array}{l}27-45 \% \text { GDP, a significant increase } \\
\text { tendency to the industrialization } \\
\text { completion }\end{array}$ \\
\hline $\begin{array}{l}\text { The share of high- } \\
\text { technology export }\end{array}$ & $17-25 \%$ of industrial export & $5-15 \%$ of industrial export \\
\hline
\end{tabular}

Source: the author's one

The comparison of the NIS in the developed and developing countries, has allowed to highlight a number of key differences that reflect fundamentally different perception of innovations.

1. The distinction in targeting is that the tasks for the NIS development are absolutely different. The aim of the NIS construction in developed countries is founding the innovative basis in all processes of society functioning, i.e. the actual implementation of sustainable innovation oriented development concept

The objectives for developing countries are limited by the following factors: 


\section{ІННОВАЦІї}

Firstly, the search for embryonic elements of the innovation process and the creation of conditions that facilitate the spread of innovation;

Secondly, the direction of every effort to overcome the "technology gap" using importing technology and the development of internal capacity for their effective use;

Thirdly, the expansion and promotion of investments aimed at the acquisition and implementation of technologies, and at the development of technological capabilities.

The aim of attainment of innovation independence is strategically important for developing countries, but this task is long term one.

2. The differences in the composition of NIS subsystems and interaction between them. Understanding of the structural NIS characteristics is important to determine the points of application of an effort to enhance innovation. Developing countries have a well-formed NIS infrastructure on macro (labor markets, financial markets, education system, etc.), meso (technological parks and platforms, thematic networks, etc.), and on micro level (innovation active enterprises of various kinds and research institutes of creation of new knowledge). It is noteworthy, that it is exactly developed countries that are in a constant search for new organizational forms of innovation operation activation. In developing countries, there is a focus on updating the existing elements and on creation of "new" ones, using the experience of developed countries.

3. The differences in the content of public policy. In developed countries, the innovation process is an embedded driver of socio-economic development, primarily through free competition, and formed market institutions. Developing countries are characterized by a limited role of government at all stages of the innovation process and lack of financial resources that the government assigns for education and science. That is why, in developing countries the formation of the state innovation policy should become the first step in the NIS formation.

Implementation of the NIS concept in developing countries requires the development of a policy directed at improving the overall innovation system configuration, in particular regarding R\&D expenditure distribution; stimulating cooperation between firms, public and private institutions; reducing regulatory barriers to the mobility of human resources. Overall, the implementation of the NIS concept should be considered as a learning process that can lead to public policy system reshaping.

4. The differences in the NIS formation mechanisms. "Borrowing" and adaptation of technologies from countries that are technology leaders have become important for the development of developing countries at the present stage. The combination of all possible methods i.e. reverse engineering, licensing, overseas trips of scientists, inviting foreign companies and experts to participate in international scientific collaboration - they are difficult to implement immediately and in combination, but these tools are used by developing countries while constructing the NIS.

5. The differences in quantitative indicators of resource provision and effectiveness of NIS functioning. In developed countries, innovations have long become the philosophy of the entire economy, and, thus, their indicators are quantitative benchmarks for the resource support of the NIS. At this stage, developing countries should actively create conditions for the perception of innovations and ensure their effective adsorption by relevant industries and enterprises, and this requires not only qualitative changes in the economy, but also orientation to quantitative performance indicators of the NIS in developed countries. In accordance, the developing countries increase the level of financial provision and staffing of the NIS development by the increasing in investments in R\&D and education, increasing the number of people with high education, increasing the number of scientific staff, etc.

Considering the listed above and other differences in the NIS development, it should be emphasized that there is an important motive of innovation intensification in developing countries, which forms a key competitive advantage in this group of countries, such as lower costs of innovation, compared with developed countries. As a result, enterprises are able to create their own "niche" on global markets. Respectively, having provided the expansion for innovation adsorption ability at the initial stages, in developing countries, the NIS should be aimed at the development of opportunities for making innovation with higher value, and this is possible only on the conditions of the creation of an effective NIS. 


\section{ІННОВАЦІї}

The understanding of the existing differences gives an opportunity to imagine the challenges that are faced by some countries, such as Ukraine, in the context of innovation development acceleration. The features of the contemporary NIS development of Ukraine are as follows:

1. The justification process of the NIS development goals should consider the fact that the processes of industrial production industrialization take place slowly, and the investment activity is declining. Therefore, the important task for Ukraine is to get (create) innovation, the use of which will increase the overall productivity in the existing industrial branches and will increase the effectiveness of science.

2. Ukraine still has certain infrastructure conditions to activate innovation, such as universities, research institutes, and factory science. However, low funding and insufficient interaction leads to an outflow of personnel from the field of science, reducing the impact of science as a whole. Taking into consideration the NIS performance indicators of Ukraine, it can be concluded about the movement in the direction opposite to that of the global trends.

3. Instead of implementing an active innovation directed policy, the state of Ukraine has taken the passive observational position. NIS formation is a priority task for the government and should be implemented on the declaration level without developing a meaningful innovative policy that should be accompanied with the formation of effective levers for innovation activation.

The understanding of the presented differences of the NIS functioning in different countries and of the features of the present stage of innovation activity in Ukraine allows to emphasize on the importance to formulate the conceptual provisions of the NIS development, which may be the first stage of innovation orientation in the development of a country (Fig. 1).

Developing the NIS concept implies reasoning for the content of the constituent elements on three levels, i.e. the theoretical, methodological and practical ones.

The scientific basis of the NIS concept is formed with the theory of economic dynamics, theory of a firm, investment and innovation theory, theory of regional economy, which allow to build structural and logical relationships between the key drivers of development in modern conditions and to determine the role of NIS in these processes.

The use of the scientific theories content and author's research have allowed to formulate the regularities of the contemporary stage of the NIS development, which should be taken into account while developing the conceptual provisions of activation of innovative processes in Ukraine. Therefore, among the most important regularities of the NIS development there are the following ones:

an innovative directivity of economic development, i.e. innovations have been recognized by scholars and practitioners as the most effective driver of all processes of human life, so the NIS formation does not have an alternative form of multilevel governance of the innovation processes of a society and economy;

constant evolution, i.e. NIS is a structure that is constantly improved, and at the same time is an adaptive mechanism of economy, that allows to adjust to the most requirements and challenges of our time by improving the forms and institutions of innovation;

up-building the resource potential, i.e. resources remain a critical factor in the innovative development and launching of mechanisms to self-development of NIS, this, in particular, includes material, financial, intellectual, information and other resources;

preservation of the leading role of a state in the initiation of innovative development, i.e. in most countries, the state continues to have an important role in NIS shaping: from the formation of innovation policy and the creation of legal and economic conditions for the transformation of enterprises into real innovation drivers to participate in advanced research projects through the use of the state budget;

the globalized nature of the result use, i.e. competitive innovations almost instantly become the object of interest on global markets, although their creation takes place in specific areas where participants are focused on the innovation process and the formation of critical resources. As a result, innovations in modern conditions operate in the globalization-localization coordinate.

These regularities allow to define the conditions in which the development of the innovation sector takes place in most countries. 


\section{ІННОВАЦІї}

The starting point of proper directing of the virtually chaotic processes of the NIS development in Ukraine should be the definition of scientific approaches, understanding of which will allow to build the overall logic of the reform process.

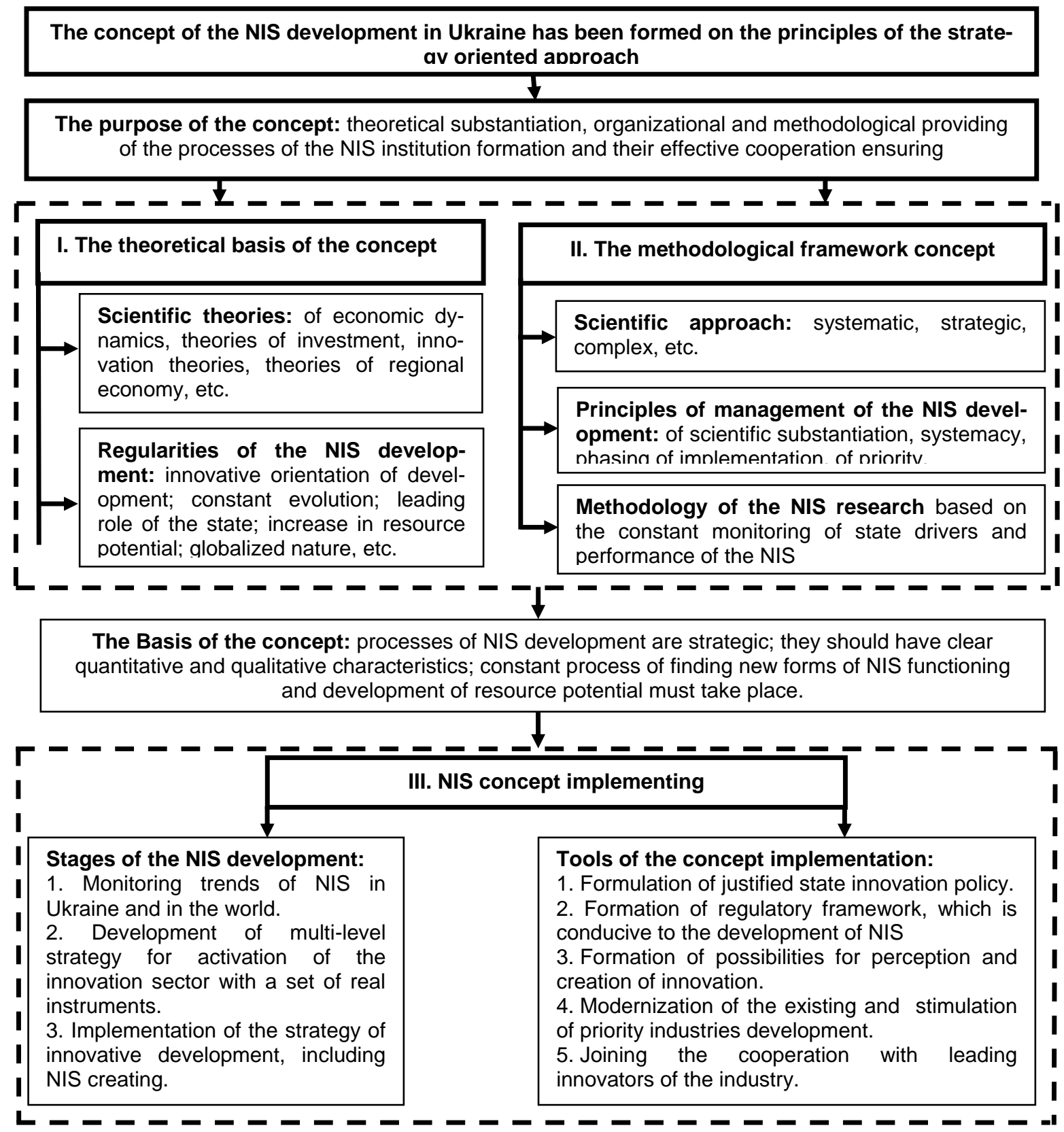

Fig. 1. The constituent elements of the NIS concept formed through strategically-oriented approach Source: the author's one

1. A strategic approach defines the necessity to form a long-term strategy of innovative development for Ukraine's economy, which would contain a set of quantitative and qualitative objectives with defined terms forecasted (expected and actual) results and the opportunity to review and adjust them 


\section{ІННОВАЦІї}

if it is necessary. In our opinion, while developing the NIS concept of Ukraine, a strategic approach should be used as a basic one.

2. A systematic approach, i.e. systemacy as a principle of NIS functioning, means that its elements should not be characterized by a mechanistic combination; they should have consistency and interaction, which eventually will provide an attainment of innovation sector onto the level of selfdevelopment.

3. A comprehensive approach determines the necessity for consideration the objectives of the NIS development on all levels of its operation (macro, meso and micro), which means the need to provide not only the development of theoretical provisions for suppling the scientific basis under the program development in a country, but also for creating a set of specific regulations, the introduction of new forms of activation processes on the level of actual participants of NIS, i.e. enterprises, educational or scientific institutions, etc.

In accordance with the current stage of the innovation sphere development in Ukraine, the following basic provisions of the concept are offered as the priority ones:

1. The process of innovative processes activation through the NIS creation should be considered as strategic ones and those that determine the prospects for the national economy on all levels of operation, and, therefore, they are uncontested.

2. The processes of the NIS development should have clear quantitative and qualitative targets as for the forms and terms of implementation, since the postponement will eventually require spending even more resources in order to receive even slight results.

3. The processes of the NIS development are complex and multidimensional, and, therefore, require the development and implementation of a scientifically grounded innovative policy aimed at the preservation of the existing and development of the necessary resource possibilities.

In order to implement the developed provisions regarding the NIS development in the practical sphere, it is necessary to apply a number of instruments for different levels of action. As for the priority measures, the following steps are advisable:

On the state level - to develop a long-term strategy of the NIS evolution; to introduce a system of the NIS efficiency monitoring according to the methods, that are used by OECD countries; to ensure formation and implementation of the state innovation policy; to develop a regulatory framework, that is conducive to the NIS development, etc.;

On the industrial enterprise level - to modernize the economy, using technological innovation that will ensure the empowerment and perception of innovation in real production; to attract strategic partners for joint development of new innovative projects; to step up export opportunities, etc.

On the research and educational institution level - to ensure the creation of complex conditions for storing, updating and development of human potential research sector; to increase the scientists' motivation and the implementation of research results in the real economy; to prevent intellectual emigration and to improve the level of economic security on this basis.

Conclusions. The complexity of the NIS formation causes even some doubts as for the effective implementation of this concept in developing countries. It means that the NIS concept content and a set of tools for implementation requires a clear, scientific justification based on a strategic approach. This long-term strategy of innovative development by improving NIS can be considered the starting point of a state policy in the innovative sphere that will enable a country to develop adequate implementation toolkit and transform it into a legislative framework, targeted and comprehensive development programs.

The vast majority of the proposed instruments for the implementation of the concept relate to systemic measures, which have a lag time of implementation, but without their action, the creation of an effective NIS is impossible.

\section{References}

1. Innovatsiina Ukraina 2020 (2015). [Innovative Ukraine] : national report / general edition by V. M. Heitsia ta in. ; NAN Ukrainy. - K., p. 336 [in Ukrainian].

2. Kasych, A. O. (2013). Dosvid formuvannia natsion-

\section{Література}

1. Інноваційна Україна 2020 : національна доповідь / за заг. ред. В. М. Гейця [та ін.] ; НАН України. - К., 2015. $336 \mathrm{c}$

2. Касич, А. О. Досвід формування національних ін- 


\section{ІННОВАЦІї}

alnykh innovatsiinykh system $v$ krainakh, shcho rozvyvaiutsia [Experience the formation of national innovation systems in developing countries]. Aktualni problemy ekonomiky, № 5 (143), pp. 46-49 [in Ukrainian].

3. Fedulova L. I. (2016). Innovatsiynist ekonomiky Yevropeyskogo soyuzu ta Ukrainy: napriamy skorochennya rozryvu [The innovation economy of the EU and Ukraine: trends gap] Economic Annals-XXI, № 156 (1-2). - pp. 22-25 [in Ukrainian].

4. Atkinson, R. D. (2014). Understanding the U.S. National Innovation System. The Information Technology \& Innovation Foundation. - p. 27 [in English].

5. Etzkowitz, H., Dzisah, J., Ranga, M. and Zhoub C. (2007). The triple helix model of innovational Universityindustry-government interaction Tech Monitor, vol. 1. pp. 1423 [in English].

6. Feinson, S. (2003). National Innovation Systems Overview and Country Cases. Vol. 1, Sec. 1, Knowledge Flows and Knowledge Collectives: Understanding the Role of Science and Technology Policies in Development. Center for Science, Policy and Outcomes, Columbia University. Retrieved from : http://www.aau.org/sites/default/files/urg/docs/nis overview country \%20cases.pdf [in English].

7. Freeman, C. (1995). The 'National System of Innovation' in historical perspective. Cambridge Journal of Economics 1995, 19, pp. 5-24 [in English].

8. Godin, B. (2007). National Innovation System: The System Approach in Historical Perspective. - Retrieved from : http://www.csiic.ca/PDF/Godin_36.pdf. [in English].

9. Lundvall, B. A. (2005). National innovation systems - analytical concept and development tool. Tenth Anniversary Summer Conference "Dynamics of industry and innovation organizations, networks and systems», Copenhagen, Denmark, June, pp. 27-29 [in English]

10. Melaas, A. and Zhang, F. (2016). National Innovation Systems in the United States and China. The Center for International Environment and Resource Policy. p. 36 [in English].

11. Sharif, N. (2006). Emergence and development of the National Innovation Systems concept. Research Policy, no. 35, pp. 745-766. [in English]

12. Seidel, U., Müller, L. Köcker, G. and Filho, G. (2013). A new approach for analysing national innovation systems in emerging and developing countries. Industry \& higher education, vol. 27, No 4, pp. 279-285 [in English].

13. Vertova, G. (2014). The State and National Systems of Innovation : A Sympathetic Critique. University of Bergamo, Working Paper, no. p. 823 [in English]. новаційних систем в країнах, що розвиваються / А. О. Касич // Актуальні проблеми економіки. - 2013. - № 5 (143). - С. 46-49.

3. Федулова, Л. І. Інноваційність економіки $€ С$ та України: напрями скорочення розриву / Л. І. Федулова // Economic Annals-XXI. - 2016. - № 156 (1-2) . - C. 22-25.

4. Atkinson, R. D. (2014). Understanding the U.S. National Innovation System. The Information Technology \& Innovation Foundation. $-27 \mathrm{p}$.

5. Etzkowitz, H., Dzisah, J., Ranga, M. and Zhoub, C. (2007). The triple helix model of innovational Universityindustry-government interaction Tech Monitor, vol. 1. p. 1423.

6. Feinson, S. (2003). National Innovation Systems Overview and Country Cases. Vol. 1, Sec. 1, Knowledge Flows and Knowledge Collectives: Understanding the Role of Science and Technology Policies in Development. Center for Science, Policy and Outcomes, Columbia University. - Mode of access: http://www.aau.org/sites/default/files/urg/docs/nis over view country \%20cases.pdf.

7. Freeman, C. (1995). The 'National System of Innovation' in historical perspective. Cambridge Journal of Economics 1995, 19, pp. 5-24.

8. Godin, B. (2007). National Innovation System: The System Approach in Historical Perspective. - Mode of access: http://www.csiic.ca/PDF/Godin_36.pdf.

9. Lundvall, B. A. (2005). National innovation systems analytical concept and development tool. Tenth Anniversary Summer Conference "Dynamics of industry and innovation organizations, networks and systems», Copenhagen, Denmark, June, 27-29.

10. Melaas, A. and Zhang, F. (2016). National Innovation Systems in the United States and China. The Center for International Environment and Resource Policy. 36 p.

11. Sharif, N. (2006). Emergence and development of the National Innovation Systems concept. Research Policy, no. 35 , pp. $745-766$.

12. Seidel, U., Müller, L. Köcker, G. and Filho G. (2013). A new approach for analysing national innovation systems in emerging and developing countries. Industry \& higher education, vol. 27, No 4, pp. 279-285.

13. Vertova, G. (2014). The State and National Systems of Innovation: A Sympathetic Critique. University of Bergamo, Working Paper, no. 823.

Бібліографічний опис для цитування :

Kasych, A. Conceptual provisions of the development of Ukrainian innovation system / A. O. Kasych, M. Vochozka // Hayковий вісник Полісся. - 2017. - № 2 (10), Ч. 2. - С. 16-23. 